\title{
Belhar: 'n Spiritualiteit van resepsie in die plaaslike gemeente
}

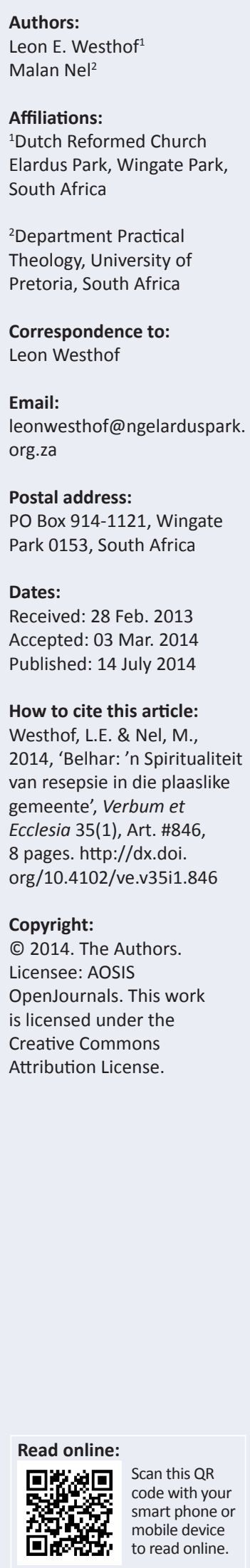

The Confession of Belhar: A spirituality of reception in the local church. The General Synod of the Dutch Reformed Church took the following decision during October 2011: 'The General Synod decides to make the Confession of Belhar part of its confessional foundation, that is, in terms of its church ordinances, and commission the Moderamen to prepare the necessary processes regarding ecclesiastical law.' This article deals with the perception of, the reception of and resistance against Belhar as confession in a local congregation, Elardus Park. The research also describes how this obstructs the development of missional focus. The main contribution of this article is to argue that the ecumenical concept's full reception should be assessed within the broader framework of building up a missional local church where a spirituality of reception is fully developed in terms of a missional positioning in Africa.

\section{Inleiding}

Die Algemene Sinode van die Nederduitse Gereformeerde Kerk (NGK) het in Oktober 2011 die volgende besluit oor die Belydenis van Belhar geneem:

Die Algemene Sinode besluit om die Belydenis van Belhar op kerkordelike wyse deel van die NG Kerk se belydenisgrondslag te maak en dra dit aan die Moderamen op om die nodige kerkordelike prosesse hieroor in werking te stel. (NGK 2011:159)

Voortvloeiend is die vraag hoe volle resepsie, wat in die moderne ekumeniese beweging as 'n tegniese term funksioneer (sien Naudé 1997:229-230, 2010:132-133; Naudé \& Smit 2000:176-178; Rausch 1986:497-508; Rusch 1988) op gemeentelike vlak tot sy reg kan kom. Volle resepsie is problematies in 'n konteks waar daar weerstand gebied word teen verandering en/of die aanvaarding van 'n nuwe belydenisskrif soos die Belydenis van Belhar. Hierdie weerstand is in 'n onlangse empiriese navorsing in die NG Gemeente Elarduspark ondersoek (Westhof 2012). Die weerstand wat gebied word in terme van volle resepsie, het 'n wesenlike invloed op die missionale selfverstaan van die plaaslike gemeente.

Gevolglik is die navorsingsprobleem wat in hierdie artikel ondersoek word, die gaping tussen die Algemene Sinode van 2011 se besluit rakende die Belydenis van Belhar en sommige plaaslike gemeentes se onwilligheid om hulle missionale roeping met Belhar as vierde belydenisskrif te defineer. Die volgende opmerking van Rusch (1988:11) beklemtoon die belang van hierdie saak: 'In 1983 Thomas Ryan called "reception" the new "holy word" of the ecumenical world.'

Die oogmerk van hierdie artikel is om aan te toon hoe volle resepsie, met sy drie komponente van common explication, common recognition en common confession (sien Naudé 1997:232, 2010:134) binne 'n raamwerk van 'n spiritualiteit van resepsie (Vischer 1984:228) op gemeentevlak gefasiliteer kan word. Hierdie vraestelling is veral relevant in die lig van die onverkwiklike geskiedenis binne die NGK-familie sedert die 19de eeu en spesifiek die historiese konflikte rakende Belhar tot op hede. Hierdie artikel wil 'n deelnemende proses ondersoek waardeur die bestaande weerstand en struikelblokke op die weg na volle resepsie binne gemeenteverband hanteer word.

Die groter konteks waarbinne volle resepsie in die gemeentepraktyk fasiliteer behoort te word, is na die mening van die outeurs die gaping tussen die missionale waarde van Belhar en die huidige weerstand daarteen binne gemeenteverband. Die oorbrugging hiervan is die uitdaging wat in hierdie artikel onderneem word. De Beer en Van Niekerk (2009:53-54) se voorstel rakende 'n 'hoër orde' van ondersoek kom ter sprake. Volgens hulle val die ekumeniese dialoog tussen die Verenigende Gereformeerde Kerk in Suider-Afrika (VGKSA) en die NGK oor kerkeenheid vas op die punt van die aanvaarding of nie-aanvaarding van Belhar en is daar 'n derde weg in hierdie situasie, naamlik die ontdekking van Belhar se missionale waarde vir alle kerke.

Belhar het binne die gereformeerde tradisie tot stand gekom en word as belydenis aangebied aan kerke binne hierdie tradisie en veral binne die familie van NG Kerke. Volle resepsie vra na 'n deelnemende proses waar die aangebode geloofsdokument eers ontdek moet word, waarna 
konsensus oor die inhoudelike verkry word en waar dit uiteindelik deel gemaak word van die volle geloofslewe van die hele gemeente (Rausch 1986:505).

In wese gaan dit om veel meer as die deelnemende studie van Belhar. Dit gaan om die gesamentlike ontdekking van die missionale waarde daarvan en hoe dit die gemeente se toekomstige missionale fokus kan verander en verskerp. Hierdie oogmerke word benader vanuit die vakdissipline van gemeentebou in die Praktiese Teologie.

Die hipotese van hierdie artikel is dat wanneer die plaaslike gemeentes Belhar oorweeg binne die raamwerk van die ekumeniese begrip van volle resepsie en gemeentebou se uitgangspunte van verandering en ontwikkeling, sal die gepaardgaande spiritualiteit van resepsie gemeentes help in hulle missionale posisionering op Afrika-bodem.

\section{Metodologiese oorwegings Participative action research en advocacy research}

In aansluiting by die probleem en doelstelling van hierdie artikel, word gebruik gemaak van'n kwalitatiewe benadering waar daar gefokus word op die insigte van participative action research (Selener 1997; Swinton \& Mowat 2006:227-253) en ook advocacy research (Osmer 2008:53).

Osmer (2008:53) beskryf advocacy research as: 'This strategy is grounded in an explicit political agenda and seeks to contribute to social change.' Hierby sluit Selener (1997:18) aan: 'Participatory research is not value-free or ideologically neutral.' Die implikasie hiervan vir hierdie artikel is duidelik: die missionale waarde van Belhar word ondersoek in die lig van die ontwikkelinge wat dit kan meebring in die gemeente se missionale fokus.

Swinton en Mowat (2006:227) gaan dan verder deur die location of power in deelnemende ondersoek aan te dui as die mense in die situasie. Hulle haal Cornwall en Jewkes (1995) soos volg aan: 'participatory research ... carried out with and by local people rather than on them' (in Swinton \& Mowat 2006:227). Die implikasie is eweneens duidelik: dit is die gemeente wat die subjek van die studie is en Belhar wat die objek van die studie is. Dit is eventueel ' $n$ studie saam met die gemeente en nie van die gemeente nie.

\section{Osmer (2008) beskryf advocacy research voorts:}

It often focuses on social issues currently being debated in the public domain and seeks to give voice to perspectives overlooked or misrepresented in such debates. It also focuses on issues emerging in social movements and organizations actively engaged in social transformation. The goal of research is to shape an action agenda for change. (p. 53)

\section{Nuwe kennis en/of nuwe praktyke}

Swinton en Mowat (2006) beskryf Praktiese Teologie as fundamentally action research en wys daarop dat action research in die sosiale wetenskappe op 'n familie van navorsingsmetodes wys waarin dit om veel meer as die inwin van nuwe kennis gaan. Hulle sê:

but also a way of enabling new and transformative modes of action. The action researcher does not simply seek to observe and understand the world ... she also seeks to change it. (p. 255)

Swinton en Mowat (2006) wys daarop dat die nuwe praktyke wat verandering teweeg moet bring, vir die praktiese teoloog om veel méér gaan as probleme wat opgelos moet word. Hulle sê:

For the practical theologian, action always has the goal of interacting with situations and challenging practices in order that individuals and communities can be enabled to remain faithful to God and to participate faithfully in God's continuing mission to the world. (p. 257)

Die implikasie hiervan vir die gemeente is om nie bloot amptelike aanvaarding al dan nie van Belhar as belydenisskrif te verkry nie, maar om die missionale waarde van Belhar te omskep in nuwe praktyke wat meer getrou aan God se missie in en deur die gemeente is.

\section{Belhar binne missionale ekklesiologie}

Binne die raamwerk van die resente ontwikkelinge in missionale ekklesiologie (sien Van Gelder \& Zscheile 2011) en spesifiek 'n trinitariese verstaan van die missiologie (Bosch 1991:390; Van Gelder \& Zscheile 2011:52-53, 102-111), word daar vervolgens op konteks en inheemswording gefokus.

De Beer (2008:67-69, 83-84) toon aan dat die NGK haarself in ' $n$ missionale gevangeskap en in die doodloopstraat van ' $n$ rasgebaseerde sendingbeleid en volksgesentreerde ekklesiologie bevind. Hy toon die historiese wortels hiervan volledig aan (sien De Beer 2008:27-40), maar sien dit veral in die beleidsdokument van die NGK, naamlik Ras, Volk en Nasie (RVN), verskillende protes-geskrifte soos StormKompas, die geïsoleerde ekumeniese wêreld van die NGK en ook Biskop Leslie Newbigin se uitspraak dat die NGK geen rol meer in Afrika te speel het nie.

De Beer (2008) defineer die missionale waarde van Belhar as volg:

Die Belhar Belydenis se missionêre waarde het te make met die kruis-kulturele dialoog in ' $n$ land met ' $n$ unieke diverse kulturele samestelling soos Suid-Afrika - met die twee oogmerke van inheemswording van die Kerk in gedagte, naamlik getrouheid aan die Evangelie en relevansie vir die wêreld. (bl. 60, De Beer se kursivering)

De Beer (2008:46-51) gebruik Leslie Newbigin se kruiskulturele dialogiese model 'as die basis van waaruit 'n nuwe verstaan van inheemswording ontwikkel kan word'.

De Beer (2008:49) tipeer dit ook as 'n 'kruis-kulturele missionêre ontmoetingsmodel' waar dit om die ontmoeting van drie sake gaan, naamlik die evangelie self, die kultuur van die boodskapdraer en die kultuur van die ontvangers. 
In hierdie verband merk Van Gelder en Zscheile (2011) op:

The gospel is not merely a possession to be passed from one person to another, a kernel that exists in whatever cultural husk is at hand, but rather a living event in, between, and beyond us that changes both parties involved in the encounter. (p. 134)

In Newbigin se model gaan dit in die kruis-kulturele missionale ontmoeting om die ontvanger wat haar of sy wêreldbeskouing krities in die lig van die Skrif beoordeel met moontlik gepaardgaande berou en verandering en wat dan weer met die draer van die Skrif in gesprek tree om ook hom of haar krities uit te daag in haar of sy eie wêreldbeskouing. Daar is dus ' $n$ voortdurende en wederkerige dialoog wat ontstaan waar bekering en vernuwing van beide die draer en die hoorder ter sprake kom en bly (De Beer 2008:49).

De Beer (2008:51) pas Newbigin se model dan toe op die verhouding tussen die NGK en die Nederduitse Gereformeerde Sending Kerk (NGSK) (nou deel van die VGKSA) en beskou dan die Belydenis van Belhar as die ontvanger (d.i. NGSK) se antwoord aan die draer van die boodskap (d.i. NGK). Hy stel dit as volg:

Newbigin se model die Belhar Belydenis sal beskryf as die begin van ' $n$ voortgaande dialoog waar beide die NG Kerk en die NGSK (VGKSA) se wêreldbeelde getoets word in die lig van die Skrif, sodat beide deur hierdie dialoog die evangelie beter kan verstaan en uitleef. Die dialoog help beide kerke met hul missie in die Suid-Afrikaanse samelewing, en daarom is die antwoord van die NGSK in die vorm van die Belhar Belydenis van groot missionêre waarde. (kursief De Beer 2008:51)

Binne die familie van NG Kerke het veral drie ander teoloë ook 'n waardevolle bydrae gelewer tot die missionale verstaan van Belhar. Die heel vroegste bydrae het gekom van prof. Phil Robinson in die boek 'n Oomblik van Waarheid, onder redaksie van G.D. Cloete en D.J. Smit. In sy artikel getiteld, 'Die Belhar-belydenis van 1982 in sendingperspektief', dui hy met 'n vyftal punte die missionale waarde aan in die lig van die opmerking dat hierdie dokument nie in die tradisionele sendingterminologie opgestel is nie (sien Robinson 1984:51-56).

Koopman (2008:164-166) ontwikkel drie diskoerse van menswaardigheid vanuit Belhar se drie temas van eenheid, versoening en geregtigheid binne 'n konteks van geweld. Vir Koopman (2008:165) lê die missionale waarde van Belhar binne die herstel van menswaardigheid (restoration of dignity) en waar die drie artikels van Belhar'n raamwerk bied vir 'the discourse on solidarity and cohesion, the discourse on embrace and participation, and the discourse on compassion and human rights'.

In deel 4 van sy boek, Neither Calendar nor Clock: Perspectives on the Belhar Confession, toon Naudé (2010:169-218) die voortgaande en kontemporêre betekenis van hierdie belydenisskrif aan. 'The last part of this book is devoted to a rereading of Belhar in the light of new questions facing us in a postliberation South Africa' (Naudé 2010:169-170).

Die ontwikkeling van die plaaslike gemeente se missionale identiteit en bedieningsgerigtheid binne gemeentebou- perspektief dien as oorweging wanneer De Beer (2008) se proefskrif oorweeg word waar hy die missionale identiteit aan die hand van Belhar ontwikkel binne plaaslike konteks met die konsep van inheemswording in gedagte. In hierdie opsig is Nel (2011) se artikel oor missionale integriteit en kontekstuele relevansie ook belangrik waar hy dit in hoofsaak stel dat 'n gemeente geen missionale integriteit het wanneer hulle nie kontekstueel relevant is nie.

\section{Empiriese navorsing in Elarduspark}

Die doel van die empiriese navorsing binne die NG Gemeente Elarduspark was om eerstens die bestaande weerstand teen Belhar te bepaal, tweedens om die lidmate se missionale verstaan van gemeentewees vas te stel en laastens om 'n verantwoordbare konklusie te maak oor die verband en wedersydse beïnvloeding van die eerste twee sake op mekaar.

In die navorsing is gefokus op die breë leierskap van die gemeente wat ewekansig geselekteer is. Die vyf vrae het direk aangesluit by die studie se gestelde probleemstelling en die teologies-teoretiese onderbou (Westhof 2012:70-71).

\section{Die geskeduleerde vrae}

Vervolgens word die vyf vrae wat vir hierdie navorsing geformuleer is, weergegee met 'n verduideliking hoe elke vraag by die probleemstelling aansluiting vind (sien Westhof 2012:70-71).

Die fokus in vraag 1 is op die vasstelling of daar weerstand teen die Belydenis van Belhar sou wees of nie. Vraag 1: 'Oor die jare heen, maar veral in die laaste tyd, was die Belydenis van Belhar baie in die nuus gewees. Wat is jou standpunt oor hierdie belydenisskrif?'

Die fokus in vraag 2 en 3 is op resepsie-teorie. Die vorige vraag, dit is vraag 1 , sluit baie nou by hierdie saak aan. Fyn onderskeid is dus getref. Hier is rekening gehou met William Rusch se definisie van resepsie (sien Westhof 2012:34). Vraag 2: 'Hoe oordeel en voel jy oor die inhoud van Belhar?' Hierdie vraag sluit dus aan by fase 1 van die prosesgedrewe aard van resepsie wat handel oor common explication. Moontlike opvolgvrae ter verheldering vanuit Rusch se definisie sluit in: 'Dink jy hierdie belydenis is in ooreenstemming met die evangelie?' en: 'Dink jy ons sou hierdie belydenis deel kon maak van die leer en lewe van ons gemeente?'

Vraag 3 sluit by die ekumeniese oorweging aan, naamlik dat die gewer uiteindelik die een is wat ontvang word en ook die Rusch-definisie waar dit gaan om die dialogiese karakter van persepsie. Vraag 3: 'Die NGSK het die Belydenis van Belhar geformuleer en na samesmelting met die NG Kerk in Afrika (NGKA) is dit nou die VGKSA wat hierdie belydenis vir ons as NGK aanbied. Om watter rede dink jy is dit vir hulle belangrik dat ons as NGK hierdie belydenis moet aanvaar?'

Die fokus in vraag 4 is op die teorie van missionale gemeentebou. Met hierdie vraag is bepaal of ' $n$ histories- 
volkskerklike en ekklesiosentriese oriëntasie aanwesig is en of die lidmaat reeds geskuif het na' $n$ missionale identiteit van kerkwees. Vraag 4: 'Hoe sien jy die doel van ons gemeente se bestaan? Hoekom is ons hier, wat is ons roeping, ons taak?'

Met vraag 5 is aangesluit by De Beer (2008:27-61) se gedagte van inheemswording as deel van die missionale oriëntasie van kerkwees. Vraag 5: 'Dink jy Belhar sou ons kon help om deel te word van Afrika in die sin dat hierdie belydenis ons kan help om in 'n etnies-diverse land soos Suid-Afrika (SA) 'n evangeliese verskil te kan maak?'

Uit die resultate kon verskeie temas geïdentifiseer word.

\section{'n Verandering in standpunt - die verlede versus die hede}

Een van die verrassendste bevindings in hierdie studie is die feit dat daar reeds 'n wesenlike verandering in die leierskap se houding en standpunte jeens Belhar ingetree het. Daar kan definitief van 'n verlede en hede gepraat word waar verlede verwys na die 1980's en vroeë 1990's toe Suid-Afrika intense politieke spanning beleef het. Die negatiewe en afwysende standpunt het verander na ' $n$ totaal ontvanklike houding.

\section{Weerstand as tema}

Oor die algemeen is daar nie ernstige of sterk besware in Elarduspark se leierskap waargeneem nie. Die drie sake wat geïdentifiseer is, is aanduidend dat dit nie wesensake behels nie.

Die eerste weerstand kan as 'n Christomonistiese oorweging getipeer word. Dit behels die oortuiginge dat alle probleme, ook rassespanninge, vanuit 'n egte verhouding met Jesus Christus uit die weg geruim kan word. Vanuit sodanige verhouding is alle veranderinge aan belydenisskrifte onnodig.

Die tweede vorm van weerstand moet eerder as onsekerheid as weerstand gestel word. Terwyl daar nie inhoudelike besware teen Belhar gerig is nie, bestaan daar onsekerheid oor Belhar as sodanig. Hierdie onsekerheid het te doen met die vertroudhede van geloofsgoedere waarmee lidmate in die kerk grootgeword het en die nuutheid van veranderinge.

Die derde vorm van beswaar het te doen met 'n onsekerheid of Belhar as ' $n$ belydenisskrif kwalifiseer. Interessant is dat die bestaande belydenisskrifte, ten spyte van uiteenlopende formate, nie as belydenisskrif in aard en wese betwyfel word nie.

\section{Die Belydenis van Belhar se korrelaat met die evangelie}

Hoewel sommige lidmate in die empiriese studie nie deeglik op hoogte was van Belhar se inhoud nie, is die bevinding deurgaans dat Belhar in ooreenstemming met die Bybelse evangelie is. Een respondent se reaksie: 'Ek het nou weer gelees en ek sien daar is niks snaaks daarin nie, dit is eintlik baie mooi' (Westhof 2012:72-73).

\section{Die Verenigende Gereformeerde Kerk se motief met die Belydenis van Belhar}

In die empiriese navorsing is navraag gedoen oor die Verenigende Gereformeerde Kerk (VGK) se motief met die aanbod van Belhar. Die eerste motief wat sterk gestel is, is kerkeenheid.

Naas kerkeenheid, het die aard van Suid-Afrika se politieke verlede as tweede motief na vore gekom. In die rassemotief wat hier aan die orde gestel is, is dit duidelik gestel dat daar geen regverdiging vir apartheid kan wees nie.

In die uitwysing van hierdie motiewe het die lidmate begrip vir die saak van kerkeenheid getoon en instemming dat apartheid nie Bybels geregverdig kan word nie.

\section{Missionale dimensie}

Die empiriese navorsing wou voorts die leierskap van Elarduspark se missionale verstaan al dan nie van kerkwees peil. ' $n$ Goed gevestigde missionale verstaan is bevind en dit hang saam met die intensionele vestiging van ' $n$ missionale visie op weeklikse basis oor baie jare in die gemeente se eredienste.

\section{Inheemswording}

Die laaste vraag in die empiriese navorsing het aangesluit by De Beer (2008:27-61) se gedagte van inheemswording as deel van die missionale oriëntasie van kerkwees. Hierdie vraag het die meeste onsekerheid geskep en tot diverse antwoorde gelei.

\section{Konklusie}

Met die verloop van tyd het daar beslis 'n verandering gekom in die wyse waarop die leierskap van Elarduspark na Belhar kyk.

Die werklike lees van die Belhar-dokument maak ook 'n verskil. Nie een lidmaat het fout gevind met die inhoud van die belydenis toe hulle dit self in geheel gelees het nie.

Die eenheid van die kerk tussen die NGK en die VGK is nie 'n probleem vir die leierskap van Elarduspark nie.

Die leierskap van Elarduspark het 'n duidelike missionale verstaan van kerkwees.

Die saak van inheemswording blyk onbekend te wees vir die leierskap. Gevolglik word die potensiële band tussen Belhar en die missionale verstaan van die gemeente op Afrikabodem nie begryp nie.

\section{Resepsie \\ Resepsie -'n werksdefinisie}

Ten diepste gaan dit in hierdie artikel om die resepsie van Belhar binne die plaaslike gemeente, maar dan spesifiek om die 'volle resepsie' daarvan. 
Naudé (1997:229-230, 2010:133-134) gebruik William Rusch (1988) se definisie van 'resepsie' om die onderskeie aksente binne die moderne ekumeniese beweging te verstaan:

Ecumenical reception includes all phases and aspects of an ongoing process by which a church under the guidance of God's Spirit makes the results of a bilateral or a multilateral conversation a part of its faith and life because the results are seen to be in conformity with the teachings of Christ and of the apostolic community, that is, the gospel as witnessed to in Scripture. (p. 31)

Naudé (2010:134) onderskei in hierdie definisie vyf dimensies:

- Die beklemtoning van die prosesgedrewe aard van resepsie wat deur verskeie fases moet gaan voordat die belydenis kerkordelik aanvaar word.

- Die dialogiese karakter van resepsie - die voortgaande gesprek binne en tussen kerke.

- Die pneumatologiese karakter van resepsie - in alles word die leiding van die Heilige Gees gesoek aangesien resepsie ten diepste die werk van die Gees is.

- Die kwalitatiewe karakter van resepsie - dit wat ontvang word moet deel van die geloof en lewe van die ontvanger (die kerk) word.

- Die kritiese karakter of kriteriologiese komponent (Naudé 1997:230) van resepsie - in welke mate die besluit of dit wat ontvang is, in ooreenstemming met die evangelie is.

Elk van hierdie dimensies in Rusch se definisie, aan die hand waarvan Naudé (1997) te werk gaan, moet prakties aandag in die plaaslike gemeente kry in die hantering van Belhar.

Ingebou in bogenoemde bespreking van die resesepsiebegrip is die uitgangspunte van gemeentebou waar die begrip 'gemeente' ernstig geneem word. Indien die aanvaarding of verwerping van Belhar bloot deur die kerkraad gedoen word, het die gemeente as sodanig daardeur nog nie geestelik gegroei nie en identifikasie vind nie plaas nie. Dit kom neer op 'n modernistiese, outoritatiewe benadering waar besluite deur ' $n$ minderheid namens die meerderheid geneem word en waar hierdie wyse van standpuntinname geestelike groei belemmer.

In die lig van die beginsels van gemeentebou behoort daar voorts wegbeweeg te word van 'n blote demokratiese proses waar die meerderheidstem deur 'n gewone stemmery nagejaag word. Hierdie wen-verloor situasie dra weinig by tot geestelike groei binne die gemeente. Beide moontlikhede van die uiteindelike aanvaarding of verwerping van Belhar moet die resultaat wees van ' $n$ proses waar aan al die dimensies van Rusch se definisie reg laat geskied is.

\section{Hindernisse op die weg na volle resepsie}

Naudé (1997:234-241, 2010:138-148) identifiseer vier faktore of hindernisse wat in hulle samehang die volle resepsie van die Belydenis van Belhar bemoeilik binne die NGK. Hoewel die empiriese navorsing binne Elarduspark aantoon dat die leierskap Belhar waarskynlik geredelik sal aanvaar, mag onderstaande hindernisse steeds in die breë gemeente teenwoordig wees. Hiermee sal in die voortgaande proses deeglik rekening gehou word.

\section{'n Hermeneutiek van suspisie - die hermeneutiese faktor}

Naudé (1997:234) sien die hermeneutiek van suspisie as 'n verdedigende leesstrategie wat die kanse op volle resepsie verskraal. Hy toon aan dat hoewel die NGK nie-teologiese fout met die Belydenis van Belhar gevind het nie, die historiese en politieke konteks die NGK genoop het om die belydenis as 'n aanval op haarself te gesien het (Naudé 2010:140-141). So is daar op wye front veel gemaak van die politieke ontstaan en intensie van Belhar wat die hermeneutiek van suspisie verhoog. Die aanvanklike etikettering van bevrydingsteologie het gou geblyk nie substansieel te wees nie, maar bevestig die verdedigende posisie wat by die NGK ingeneem is.

\section{Resepsie en doksologie - die liturgiese faktor}

Naudé (1997:235, 2010:142) toon 'n duidelike band aan tussen liturgie en resepsie binne die ekumeniese teologie. Waar liturgiese aktiwiteite die proses van resepsie kan fasiliteer en help, is daar binne die NGK egter verskeie struikelblokke wat die saak eerder bemoeilik. Hy verwys eerstens na die studie van prof. Bethel Müller in 1987 wat 'n analise gemaak het van Afrikaanse prediking op televisie en radio. Die resultate dui daarop dat die prediking binne Afrikaanse kerke fundamenteel individualisties en piëtisties is en ver verwyderd staan van Belhar se temas van eenheid, versoening en geregtigheid. Tweedens verwys Naudé (1997:235) na die Algemene Sinodale Kommissie (ASK) se brief van 11 November 1996 waarin daar gevra word dat gemeentes 'biddende aandag' aan die belydenis sal gee. Na sy oordeel, waarskynlik ten regte, vind gebed as liturgiese moment toegespits op Belhar nie op gemeentelike vlak plaas nie. Derdens verwys hy na die belang van die sakramentsviering en gesamentlike aanbidding en die tragiese geskiedenis binne die NGK-familie (Naudé 2010:143). Hy wonder of die gebeure van 1857 en 1982 nie negatiewe spieëlbeelde van mekaar is nie. In 1857 het die wit lidmate nie kans gesien om langer nagmaal saam met hulle anderskleurige broers en susters te vier nie en in 1982 by die Ottowa-vergadering van die Wêreldbond van Gereformeerde Kerke het die NGSK op hulle beurt nie kans gesien om die nagmaal saam met die afvaardiging van die NGK te vier nie. Die nagmaal het in die geskiedenis dus verdeel, eerder as verenig. In hierdie verband is prof. Nico Smith se beskrywing van 'n gesprek met die Switserse prediker, Walther Lüthi, veelseggend toe laasgenoemde gesê het: 'Ek sou miskien nog afsonderlikheid in die kerk kon begryp, maar afsonderlikheid by die nagmaaltafel? Dit kan ek nooit' (Smith 2010:33).

\section{Opposisionele sosiale posisies - die sosiale faktor}

Die verskillende lidmate van die NGK-familie leef met geweldige sosiale gapings tussen hulle. Dit was veral onder die apartheidsjare waar, maar die nawerking daarvan geld vandag steeds. Hieroor sê Naudé (2010:145): 'Living in physically separate worlds in the same country led to separate social constructions of reality and ultimately to opposing theological judgements about that reality.' 
Die NGK het 'n onvermoë gehad om die lyding van die sogenaamde dogterkerke te verstaan en het ook nie die kairos-aard van die tydsgewrig begryp nie. Naudé (1997) sien dit veral in die 1990-besluit van die NGK wat lui:

Die ASK het begrip dat die Belharbelydenis met groot erns deur die sinode van die NG Sendingkerk behandel en aanvaar is en dat die inhoud sake hanteer wat veral vir die NG Sendingkerk van wesenlike belang is. (bl. 236)

Naudé (1997:236, 2010:144) se ietwat siniese konklusie is dat Marcionisme, Arianisme, Epikurisme en Pelagianisme vir die NGK met sy Europees-gesentreerde teologie veel belangriker is. Belangriker is egter sy konklusie op voetspoor van Barth (1956:630) dat as daar by 'n belydenis nie 'n duidelike 'Nee' is nie, is die ' $\mathrm{Ja}^{\prime}$ ' wesenlik ' $\mathrm{n}$ kragtelose ' $\mathrm{Ja}^{\prime}$. In soverre as wat die NGK nie die 'Nee' grondig verstaan nie, met ander woorde in gebreke bly om die lyding te begryp, sal hierdie disposisie 'n struikelblok bly in die weg na volle resepsie. Konkrete blootstelling en 'n deurleefde ervaring van kerklike verskeurdheid, onversoenbaarheid en ongeregtigheid is 'n voorvereiste vir die 'Ja' van Belhar se drieledige fokus van kerkeenheid, versoening en geregtigheid.

\section{Nie-teologiese faktore - die identiteitsfaktor}

Vischer sê (1984):

\begin{abstract}
Over the years, confessional differences have become combined with many additional factors. Frequently, confessional positions are not divided by a concern for the purity of their teaching. The real motive is often simply preservation of one's identity which has developed over the course of history ... These may be matters of language, ethnic identity, national pride, or other things. For this reason the ecumenical movement must pay attention to these ancillary factors. By breaking through these secondary barriers - which are no less resistant for all that - the church will win freedom for its process of reception. (p. 232)
\end{abstract}

Naudé (2010:147, sien ook 1997:238-239) verwys na verskeie bronne van navorsing wat reeds binne die NGK gedoen is met die fokus op selfverstaan en identiteit. In hoofsaak kom dit neer op 'a decisive structure in the myth of the volk' en 'the overriding urge for preservation' en 'a clear delineation between the insiders and the outsiders, the "us" and the "enemy" en 'mounting fear and an apocalyptic mindset in the face of social change' en 'an astonishing lack of historical consciousness of the context' (Naudé 2010:147).

In aansluiting hierby kan ook verwys word na die proefskrif van Boshoff (2011) waarin sy empiriese navorsing aantoon dat die veranderinge in die samelewing tans 'n onafgehandelde treurproses binne die NGK tot gevolg het. Die veranderinge wat lei tot belewenisse van verlies met al die gepaardgaande treursimptome, roep om 'n begeleide rouproses sodat die selfverstaan en identiteitsvorming van die NGK weer op vaste baan kan kom.

Naudé (1997:239-240) toon ten regte aan dat binne hierdie ingrypende sosiale veranderinge lidmate die kerk as veilige hawe wil behou waarin ' $n$ vorm van selfbeskikking gekoester kan word. Die navorsing van Marais en Hendricks (sien
1996:146-151) oor identiteitsverandering binne gemeentes in die Suid-Afrikaanse konteks sedert 1994, toon vanuit ' $n$ strukturalistiese benadering aan dat die onderliggende strukture wat die onbewustelike prosesse van transformasie in 'n gemeenskap stuur en beheer, 'n wesenlike rol speel in die selfverstaan van 'n gemeente. Hulle aanduiding van die NGK se spiritual exile (Marais \& Hendricks 1996:147) en huidige myths vacuum (Marais \& Hendricks 1996:149) open nuwe moontlikhede vir 'n nuwe missionale verstaanshorison binne die NGK.

Bogenoemde hindernisse wys op die noodsaaklikheid om 'n 'spiritualiteit van resepsie' (Vischer 1984:228) te ontwikkel.

\section{'n Spiritualiteit van resepsie 'n Spiritualiteit van resepsie: Die kritiese aard van resepsie}

In aansluiting by Rusch se definisie oor die kritiese aard van resepsie sê Vischer (1984:228): 'Generally speaking, the churches evaluate the texts on the basis of whether they are in accord with the teaching and practice of their own tradition.'

In die gemeentepraktyk beteken dit gewoon dat die teks van Belhar indringend en krities gelees en bestudeer moet word.

Daarmee saam gaan egter die bereidheid om van die sogenaamde belemmerende ontstaansgeskiedenis van Belhar afskeid te neem (sien Naudé 2010:141). Die perspektief van respondent $B$ (in die empiriese studie wat binne die NG Gemeente Elarduspark onderneem is, Westhof 2012:72), is ter sake in sy aanduiding dat Belhar in die 1980's gelees is deur 'n veiligheidsbril, maar nou deur 'n versoeningsbril gelees word.

In hierdie opsig help Barth (1956) ons baie:

Of course, in almost all ecclesiastical confessions the theological preparation as well as the way in which the decision was made is open to question and dispute. But it is not the level and content of the theological debates directly preceding its proclamation which decides the authority of a confession, although often they have failed notoriously to reach the height which is to be desired. Nor is it the legal correctness nor the human 'decorum' observed or not observed in reaching the decision, although it is to be deplored when the latter is wanting. What really decides its authority is simply its content as scriptural exposition, which is necessarily confirmed or judged by Scripture itself. (p. 638)

En verder: 'A confession which stands at this point has authority even if it was adopted in the most disorderly tumult' (Barth 1956:638).

Die deurslaggewende vraag is of Belhar se waarheid van destyds, steeds ' $n$ waarheid vir nou is. In aansluiting hierby word 'n spiritualiteit van resepsie teenoor 'n hermeneutiek van suspisie gestel. By laasgenoemde gaan dit om 'n verdedigende leesstrategie wat veral gebore word uit die verdagmaking van die opstellers en aanklagte soos beïnvloeding vanuit die teologie van bevryding. 


\section{'n Spiritualiteit van resepsie: Die pneumatologiese aard van resepsie}

'n Egte spiritualiteit van resepsie gaan volgens Vischer (1984:228) verder as net die kritiese lees van die belydenisdokument: 'They do not ask the contrary question: to what extent does the ecumenical consensus call into question and correct the teaching and practice of their own church?' 'n Spiritualiteit van resepsie vra dus nie net dat die NGK Belhar krities lees nie, maar ook die belydenis sal toelaat om die soeklig op haar te laat val. Die bereidheid om in gesprek te tree, vra kritiese denke en oorweginge, maar ook die afbreek van eie weerstande in die moontlikheid van prysgawe en verandering. Die pneumatologiese karakter van resepsie, soos deur Rusch aangedui, kom dus ook aan die orde. 'n Spiritualiteit van resepsie behels dus nie net die bereidheid om Belhar ernstig te lees en te bestudeer nie, maar ook om aangespreek te word en eventueel self te verander. 'n Kritiese uitdaging om te oorweeg sou wees in watter mate het Belhar evangeliese en profetiese lig laat val op die heersende politiek van apartheid destyds binne die NGK.

\section{'n Spiritualiteit van resepsie: Die dialogiese aard van resepsie}

Die resepsie ter sprake dui nie net op die belydenisdokument nie, maar ook op die mense wat dit aanbied. In die geval van Belhar gaan dit oor die mense binne die NGK-familie, die mense met wie die NGK 'n baie lang, historiese pad gestap het. Dit gaan om die geloofsgenote met wie daar 'n gedeelde geskiedenis op 'n gedeelde Afrika-bodem bestaan. Die dialogiese karakter van resepsie in Rusch se definisie kom hier dus ter sprake. Dit is nie bloot 'n belydenisdokument wat gelees en bestudeer word nie. Dit is mense, spesifieke mense, wat ontvang word, na wie geluister word en met wie in gesprek getree word en wie uiteindelik geantwoord word.

\section{'n Spiritualiteit van resepsie: Die kwalitatiewe aard van resepsie}

Die kwalitatiewe aard van resepsie het met die geloof en lewe van die gemeente te doen (Naudé 2010:134). Hier word veral gedink aan die kategese en liturgie. Daar bestaan reeds liturgiese materiaal wat kan meewerk aan die vestiging van 'n spiritualiteit van resepsie. Dit sluit in liedere en verwerkings sodat die gemeente en liturg die inhoud dialogies hardop kan verbaliseer. Rausch (1986:508) sê: 'Ecumenical groups might reflect together on a statement during a particular liturgical season such as Lent or Advent.'

\section{'n Spiritualiteit van resepsie: Die prosesgedrewe aard van resepsie}

Die laaste saak in Rusch se definisie wat nog nie aangespreek is nie, is die element van resepsie as prosesgedrewe aangeleentheid. Drie elemente kom ter sprake, naamlik motiveringsbronne (sien Callahan 1987:76-83), konflikhantering (Nel 1994:133-135) en strategiese programme met duidelike doelwitte (Nel 1994:181-202).

Callahan (1987:76) onderskei vyf motiveringsbronne (d.i. compassion, community, challenge, commitment en reasonability) en voeg 'n sesde een (hope) by (Callahan 2010:21-29). Nel (1994) kom hieroor tot die gevolgtrekking:

'n Leraar sal ... moet insien dat slegs die oordra van informasie, hoe logies en deurdag ook al, nie die uitwerking sal hê waarop hy hoop nie. Wat in hierdie verband van besondere belang is, is om seker te maak wat mense op voetsoolvlak motiveer. (bl. 132)

'n Algemene waarneming van die inhoud van die briewe in koerante asook die inhoud van sinodale debatvoering oor Belhar, is genoegsame aanduiding dat die motiveringsbronne wat Callahan onderskei, ' $n$ waardevolle bydrae lewer in die leierskap se hantering van die prosesgedrewe aard van resepsie.

Hoewel die empiriese navorsing onder die leierskap van Elarduspark nie weerstand teen die Belydenis van Belhar bevind het nie, sal dit in die opinie van hierdie outeurs dwaas wees om nie van Boshoff (2011) se navorsing oor die treurprosesse en rouprosesse binne die NGK kennis te neem nie. Sy tweeledige kernbevinding behels die volgende: 'Langdurige, onvoltooide, kollektiewe treur- en rouprosesse kniehalter goedbedoelde gemeenteboupogings in gemeentes van die NG Kerk se Noordelike Sinode.' En tweedens 'die heersende gemeentebouteorie van die NG Kerk behoort verryk te word met kontekstuele perspektiewe op verandering, verlies en treur, asook perspektiewe op intensionele, gemeentelike rou' (Boshoff 2011:379). Wat Boshoff dus uitwys, is dat daar verlammende faktore in die Suid-Afrikaanse samelewing teenwoordig is wat in die oorweging van motiveringsbronne verreken moet word.

Wat konflikhantering aanbetref: die verskyning van die bundel Belhar Geweeg is reeds 'n aanduiding dat die toekomstige proses wat in die NGK in die vooruitsig gestel word, nie sonder konflik gaan verloop nie. Die hantering van konflik binne die plaaslike gemeente is deel van die resepsieproses.

Wat die strategiese programme en doelwitbeplanning aanbetref, word beoog om binne Elarduspark grotendeels aan te sluit by die Taakspan Belhar se vooruitskouinge vir 2013.

\section{'n Spiritualiteit van resepsie: 'n Missionale verstaan van kerkwees}

Ter aanvulling van Rusch se vyfledige verstaan van resepsie, word dit hier aangevoer dat 'n spiritualiteit van resepsie makliker gerealiseer sal word binne 'n missionale verstaan van kerkwees teenoor 'n volkskerklike verstaan. Wanneer die missionale verstaan binne 'n NGK-konteks uitgebrei word om die konsep van inheemswording te inkorporeer, sal gevorder word met die begrip dat die NGK en haar lidmate wesenlik deel van Afrika is en nie bloot 'n roeping binne Afrika het nie. Respondent F (sien Westhof 2012:87), bevestig hierdie standpunt met die beskouing dat die NGK se tradisionele belydenisskrifte dalk vreemd vir Afrika is en dat die Belydenis van Belhar 'n eie verwoording is. Die versterking van hierdie insig, naamlik dat Belhar kan help om aan die missionale aard van kerkwees op Afrika-bodem gestalte te gee, kan 'n spiritualiteit van resepsie bevorder. 


\section{Volle resepsie}

Uit bogenoemde is dit duidelik dat 'n spiritualiteit van resepsie die moderne ekumeniese beweging se begrip van 'volle resepsie' ten doel het.

Daarom is dit ten diepste ' $n$ intensionele aangeleentheid, net soos gemeentebou as proses intensioneel is. Dit vereis beplanning en doelbewuste integrering met gemeentebou.

In terme van gemeentebou kom veranderingsbestuur ter sprake. 'n Spiritualiteit van resepsie het die inherente veronderstelling dat verandering plaasvind en dit is waarmee gemeentebou besig is. Binne die raamwerk van hierdie artikel behels dit die verandering en groei in missionale kerkwees op Afrika-bodem. Nuwe praktyke moet gevestig word wat verandering teweeg bring (Swinton \& Mowat 2006:257). Daar moet besluite geneem word oor strategiese aksiestappe ter bereiking van doelwitte rakende 'n spiritualiteit van resepsie, want in die woorde van Nel (1994:196): 'Doelwitte bereik nie hulleself nie.'

\section{Gevolgtrekking}

Die hantering van die Belydenis van Belhar binne 'n plaaslike gemeente moet die beginsels van gemeentebou genoegsaam honoreer binne missionale perspektief. Die ignorering hiervan binne 'n oorwegend demokratiese hantering, dra nie net die kiem van kerklike skeuring nie, maar ook die potensiaal om die gemeente te beroof van 'n kosbare geleentheid tot geestelike groei op Afrika-bodem. Die uiteindelike vraag is nie: 'Wat stem julle?' nie, maar 'Wat wil U, Here?' (De Beer 2008:158).

Met Newbigin se model in gedagte, waarna in hierdie artikel verwys is, word dit gestel dat indien die Belydenis van Belhar nie aanvaar word nie, dit die NG Kerk in die posisie plaas waar sy nuut moet dink oor haar missionale posisie op Afrika-bodem.

In Elarduspark is daar oor 'n lang periode reeds baie gedoen in terme van liturgie en prediking om direk en indirek die Bybelse inhoud van Belhar aan die orde te stel. Voorts: pogings om 'n missionale verstaan van kerkwees teologies en prakties te vestig, word sedert die begin van die gemeente se ontstaan intensioneel gedoen. Met goeie reg kan dus beweer word dat die empiriese navorsing aantoon dat 'n spiritualiteit van resepsie in al sy dimensies in Elarduspark gevestig word.

\section{Erkenning \\ Mededingende belange}

Die outeurs verklaar dat hulle geen finansiële of persoonlike verbintenis het met enige party wat hulle nadelig kon beïnvloed in die skryf van hierdie artikel nie.

\section{Outeursbydrae}

L.E.W. (Nederduitse Gereformeerde Kerk Elardus Park) se M-skripsie 'Die Opbou van 'n Missionale Gemeente en die Resepsie van die Belydenis van Belhar in die NG Gemeente Elarduspark' is in 2012 voltooi onder leiding van M.N. (Universiteit van Pretoria).

\section{Literatuurverwysings}

Bosch, D.J., 1991, Transfoming Mission. Paradigm Shifts in Theology of Mission, Orbis Books, New York.

Boshoff, W.S., 2011, 'Gemeentebou en die begeleiding van rouprosesse in ' $n$ konteks van omvattende verandering', PhD-proefskrif, Departement Praktiese Teologie, Universiteit van Pretoria, Pretoria.

Boshoff, W.S., 2012, 'Gemeentes as begeleiers van kollektiewe rouprosesse', Verbum et Ecclesia 33(1), Art. \#726, 9 pages. http://dx.doi.org/10.4102/ve.v33i1.726

Callahan, K.L., 1987, Twelve Keys to an Effective Church: The Leaders'Guide, Harper Collins Publishers, New York.

Callahan, K.L., 2010, Twelve Keys to an Effective Church: Strong, Healthy Congregations Living in the Grace of God, Jossey-Bass, San Francisco.

De Beer, J.M., 2008, 'Die missionêre waarde van die Belhar Belydenis vir die NG Kerk: Instrument tot inheemswording', PhD-proefskrif, Departement Godsdiens- en Sendingwetenskap, Universiteit van Pretoria, Pretoria.

De Beer, J.M. \& Van Niekerk, A.S., 2009, 'Die missionêre waarde van Belhar en die NG kerk-familie se herenigingsgesprek', Nederduitse Gereformeerde Teologiese Tydskrif 50(1\& 2), 50-65.

Koopman, N., 2008, 'On violence, the Belhar Confession and human dignity', Nederduitste Gereformeerde Tydskrif 49(3\&4), 159-166.

Marais, F.J. \& Hendricks, J.H., 1996, 'What happens when congregations try to change their identity? Lessons from the stories of South African congregations', Nederduitse Gereformeerde Teologiese Tydskrif 37, 146-151.

Naudé, P.J., 1997, 'Die Belharstryd in ekumeniese perspektief', Nederduitse Gereformeerde Teologiese Tydskrif 38(3), 226-243.

Naudé, P.J., 2010, Neither Calendar Nor Clock: Perspectives on the Belhar Confession, Wm. B. Eerdmans, Grand Rapids.

Naudé, P.J. \& Smit, D.J., 2000, “"Reception” - ecumenical crisis or opportunity for South African churches?', Scriptura 73, 175-186.

Nederduitse Gereformeerde Kerk in Suid-Afrika (NGK), 1990, Agenda en Handelinge van die agste vergadering van die Algemene Sinode van die Nederduitse Gereformeerde Kerk, 16-25 Oktober 1990, te Bloemfontein, NG Sendingpers, Bloemfontein.

Nederduitse Gereformeerde Kerk in Suid-Afrika (NGK), 2011, Agenda van die veertiende vergadering van die Algemene Sinode van die Nederduitse Gereformeerde Kerk, 10-14 Oktober2011, te Birchwood Konferensiesentrum, Boksburg, CLF-Drukkers, Bloemfontein.

Nel, M., 1994, Gemeentebou, Orion, Halfway House.

Nel, M., 2011, 'Missionale integriteit en kontekstuele relevansie', HTS Teologiese Studies/Theological Studies 67(3), Art. \#1084, 9 pages. http://dx.doi.org/10.4102/

Osmer, R.R., 2008, Practical Theology, Grand Rapids, Wm. B. Eerdmans.

Rausch, T.P., 1986, 'Reception Past and Present', Theological Studies 47, 497-508. http://dx.doi.org/10.1177/004056398604700307

Robinson, P.J., 1984, 'Die Belhar-belydenis van 1982 in sendingperspektief', in G.D. Cloete \& D.J. Smit (reds.), 'n Oomblik van Waarheid, bl. 49-59, Tafelberg, Kaapstad.

Rusch, W.G., 1988, Reception: An Ecumenical Opportunity, Fortress Press, Philadelphia.

Selener, D., 1997, Participatory action research and social change, The Cornell ParticipatoryAction Research Network, New York.

Smith, N., 2010, Mosaiek van mense: Ontmoetings wat my denke en lewe radikaal verander het, Bybel-Media, Wellington.

Swinton, J. \& Mowat, H., 2006, Practical Theology and Qualitative Research, SCM Press, London.

Van Gelder, C. \& Zscheile, D.J., 2011, The Missional Church in perspective: Mapping trends and shaping the conversation, Baker Academic, Grand Rapids.

Vischer, L., 1984, 'The process of "reception" in the ecumenical movement', MidStream 23, 221-233.

Westhof, L.E., 2012, 'Die Opbou van 'n missionale gemeente en die resepsie van die Belydenis van Belhar in die NG Gemeente Elarduspark', M-skripsie, Departement Praktiese Teologie, Fakulteit Teologie, Universiteit Pretoria. 